\title{
Effects of ionenes on structure and catalytic activity of cobalt phthalocyanine. Part 4. Reaction mechanism and immobilization of the catalyst on latex particles
}

Citation for published version (APA):

Herk, van, A. M., Streun, van, K. H., Welzen, van, J., \& German, A. L. (1989). Effects of ionenes on structure and catalytic activity of cobalt phthalocyanine. Part 4 . Reaction mechanism and immobilization of the catalyst on latex particles. British Polymer Journal, 21(2), 125-132. https://doi.org/10.1002/pi.4980210206

DOI:

10.1002/pi.4980210206

Document status and date:

Published: 01/01/1989

Document Version:

Publisher's PDF, also known as Version of Record (includes final page, issue and volume numbers)

\section{Please check the document version of this publication:}

- A submitted manuscript is the version of the article upon submission and before peer-review. There can be important differences between the submitted version and the official published version of record. People interested in the research are advised to contact the author for the final version of the publication, or visit the DOI to the publisher's website.

- The final author version and the galley proof are versions of the publication after peer review.

- The final published version features the final layout of the paper including the volume, issue and page numbers.

Link to publication

\footnotetext{
General rights

- You may freely distribute the URL identifying the publication in the public portal. follow below link for the End User Agreement:

www.tue.nl/taverne

\section{Take down policy}

If you believe that this document breaches copyright please contact us at:

openaccess@tue.nl

providing details and we will investigate your claim.
}

Copyright and moral rights for the publications made accessible in the public portal are retained by the authors and/or other copyright owners and it is a condition of accessing publications that users recognise and abide by the legal requirements associated with these rights.

- Users may download and print one copy of any publication from the public portal for the purpose of private study or research.

- You may not further distribute the material or use it for any profit-making activity or commercial gain

If the publication is distributed under the terms of Article $25 \mathrm{fa}$ of the Dutch Copyright Act, indicated by the "Taverne" license above, please 


\title{
Effects of Ionenes on Structure and Catalytic Activity of Cobaltphthalocyanine, Part 4.* Reaction Mechanism and Immobilization of the Catalyst on Latex Particles
}

\author{
Alex M. van Herk, Karel H. van Streun, Joke van Welzen \& Anton L. German $\ddagger$ \\ Laboratory of Polymer Chemistry, Eindhoven University of Technology, \\ PO Box 513, 5600 MB Eindhoven, The Netherlands
}

(Received 5 April 1988; revised version received 2 November 1988; accepted 4 November 1988)

\begin{abstract}
The catalytic oxidation of 2-mercaptoethanol was investigated kinetically for the system cobalt(II)phthalocyanine-tetra (sodium sulphonate) in the presence of poly(quaternary ammonium salts) at $\mathrm{pH}=8.85$. From a comparison with other kinetic data a reaction mechanism could be proposed in which the specific effects of the polyelectrolyte become manifest. The effect of ionic strength on the catalytic activity was also studied.

The soluble catalytic system was immobilized on latex particles by using a polymeric soap containing quaternary ammonium groups. The latex particles with the ammonium groups at the surface were used to bond the cobalt catalyst by ionogenic interaction. Using this latex supported polymeric catalyst the activity of its homogeneous counterpart could be maintained while at the same time immobilization was accomplished.
\end{abstract}

Key words: cobalt(II)phthalocyanine-tetra (sodium sulphonate), ionenes, catalysis reactive latices, thiol oxidation, kinetics, mechanism, emulsion polymerization.

\section{INTRODUCTION}

In our laboratory the oxidation of thiols into the corresponding disulphides catalyzed by metalphthalocyanine complexes is used as a model reaction for the study of the effects polymers may exert on catalytic reactions. ${ }^{1-5}$ This catalytic reaction is being used industrially in the so-called Merox oil 'sweetening' process.

Investigations by Schutten and $\mathrm{Zwart}^{4}$ and Brouwer et al. ${ }^{5}$ have revealed that the addition of basic or cationic polymers strongly promotes the

* For part 3: see Ref. 3.

$\neq$ To whom all correspondence should be addressed. catalytic activity. In particular the influence of ionenes (poly(quaternary ammonium salts)) (Fig. 1) on the structure and catalytic activity of cobalt(II)phthalocyanine-tetra (sodium sulphonate) $\left(\mathrm{CoPc}\left(\mathrm{NaSO}_{3}\right)_{4}\right)$ (Fig. 2) was studied extensively. ${ }^{1-3}$

The ionenes are very suitable for studying polymeric effects because of their $\mathrm{pH}$-independent cationic charge and the easy control of charge density by syntheses of ionenes with different spacings between the ammonium groups ( $x$ and $y$ in Fig. 1).

In order to reach a full understanding of the polymeric effects on the catalytic process, the reaction mechanism has to be elucidated in as much detail as possible. Therefore, in our previous kinetic 
<smiles>[Y][N+](C)(C)CCCCCCCCCCCC</smiles>

Fig. 1. Structure of $x, y$-ionenes $\left(\mathrm{X}=\mathrm{Br}^{-}, \mathrm{OH}^{-}\right.$, etc.).

studies, we varied several reaction parameters independently; $\mathrm{pH}^{6}{ }^{6}$ ionic strength, ${ }^{5}$ thiol concentration and oxygen concentration, ${ }^{2}$ polymer concentration $^{6}$ and charge density on the polymer. ${ }^{5}$

In the mechanistic interpretation of the kinetic data the structure of $\mathrm{CoPc}\left(\mathrm{NaSO}_{3}\right)_{4}$ in the presence of the ionenes should also be taken into account. Structural investigations $\mathrm{s}^{1,3}$ revealed that the catalyst is mainly present as a straight dimeric species (without a bridging ligand) in the presence of the 2,4-ionene. Furthermore, it was found (rather surprisingly) that $\mu$-peroxo bridged dimers were not formed when the ionene-bound cobalt complex came in contact with oxygen, this in sharp contrast to the polymer-free cobalt complex solution.

In a first kinetic study we found that these structural effects also have an impact on the kinetics. $^{2}$ The $\mathrm{CoPc}\left(\mathrm{NaSO}_{3}\right)_{4}$ catalyzed thiol oxidation follows the simple two-substrate Michaelis-Menten rate law in the presence of ionenes, ${ }^{2}$ whereas in the polymer-free catalytic reaction the kinetics are much more complicated. ${ }^{7}$

Insight into the reaction mechanism can lead to an optimization of the catalytic system, leading to higher activities and application to a wider variety of substrates. Therefore, in this paper we present a reaction mechanism in the presence of ionenes.

Our catalytic reaction cycle is extremely fast, having up to 4000 turnovers per second. ${ }^{2}$ It is a challenge to immobilize such a fast catalytic system while maintaining the high reaction rates of the

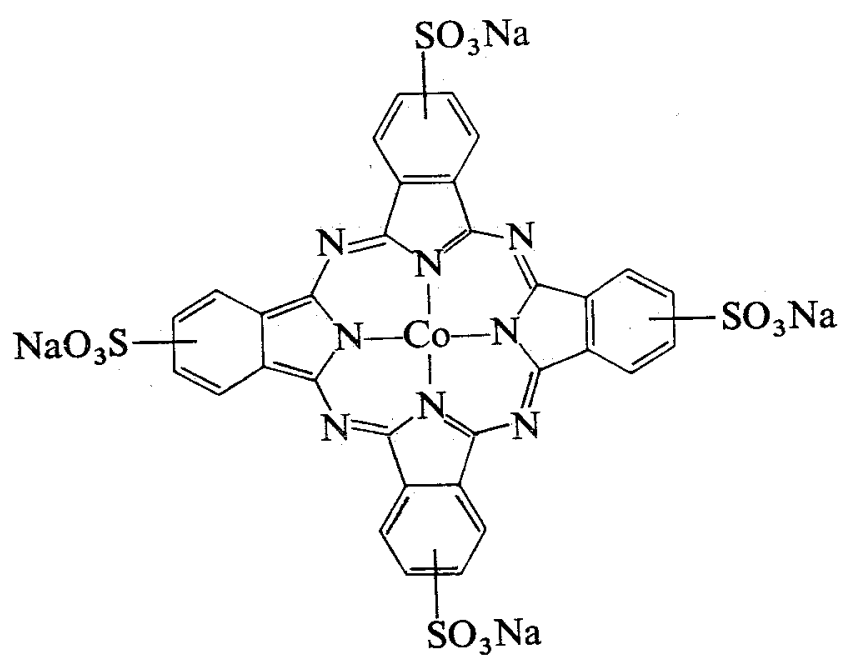

Fig. 2. Structure of $\mathrm{CoPc}\left(\mathrm{NaSO}_{3}\right)_{4}$. soluble catalytic system; so far we have not succeeded in this. To reach this goal we have to turn to a completely new and unconventional approach: the immobilization of $\mathrm{CoPc}\left(\mathrm{NaSO}_{3}\right)_{4}$ on latex particles. In this paper we give our first results on the catalytic activities of these new reactive latices based on $\mathrm{CoPc}\left(\mathrm{NaSO}_{3}\right)_{4}$ immobilized on cationically charged latex particles.

\section{EXPERIMENTAL}

\subsection{Polymer syntheses}

2,4-Ionene was synthesized according to Rembaum et al. ${ }^{8}$ The reagents were obtained from Fluka AG (purum) and used without further purification. $\bar{M}_{n}$ of the ionene was 6300 , as determined by titration with hydrochloric acid after terminating the product with amine groups. ${ }^{6}$

The block co-polymer, consisting of blocks of 4poly(vinylpyridine) and polystyrene $(90: 10 \mathrm{~mol}: \mathrm{mol}$, Polyscience), was quaternized with methyliodide according to Ishizu et al. ${ }^{9}$ and Kurihara et al., ${ }^{10}$ resulting in a polymeric surfactant type of block copolymer (abbreviated as PS-qPVP) (Fig. 3) that can be used as an emulsifier in emulsion polymerizations. The quaternization was $\simeq 100 \%$ complete according to the disappearance of the infrared absorptions at $1460 \mathrm{~cm}^{-1}$ and $1595 \mathrm{~cm}^{-1}$ and the appearance of two new absorptions at $1490 \mathrm{~cm}^{-1}$ and $1630 \mathrm{~cm}^{-1}{ }^{10}$

The charged latex was synthesized by mixing $9 \mathrm{~g}$ water, $60 \mathrm{mg}$ potassium carbonate, $0.51 \mathrm{~g}$ PS-qPVP, $0.92 \mathrm{~g}$ styrene (distilled) and $0.33 \mathrm{~g}$ divinyl benzene (Merck, technical grade, distilled). This mixture was agitated and heated to $60^{\circ} \mathrm{C}$. Finally, $34 \mathrm{mg}$ of the initiator 4,4'-azo-bis-4-cyanopentanoic acid was added. The reaction conditions were maintained for $24 \mathrm{~h}$, resulting in a monomer conversion of $\simeq 100 \%$.

The purification of the latex particles was carried out by using a Dowex $50-\mathrm{X} 4$ cationic ion exchanger according to the method introduced by Vanderhoff et al. ${ }^{11}$ in combination with the serum-replacement method. More details of this cleaning procedure will be published separately. ${ }^{12}$ After ultrafiltration with a Micropore $50 \mathrm{~nm}$ filter, the amount of ammonium groups in the serum turned out to be lower than $2 \times 10^{-7} \mathrm{~mol} \mathrm{dm}^{-3} \cdot{ }^{12}$ The diameter of the latex

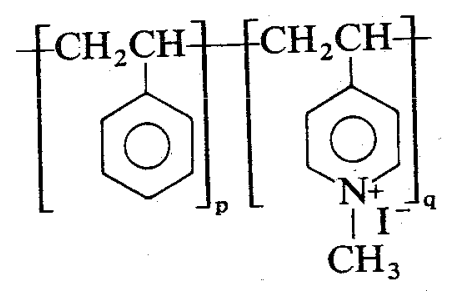

Fig. 3. Structure of PS-qPVP. 
particles was determined by scanning electron microscopy. The nitrogen content of the latex particles, after drying, was determined by elemental analysis and from this value the nitrogen concentration in the latex stock liquid was calculated.

Polymer concentrations were expressed as the concentration of ammonium groups $\left(\left[\mathrm{N}^{+}\right]\right.$in mol dm ${ }^{-3}$ ).

\subsection{Other materials}

CoPc(NaSO $)_{4}$, kindly provided by Dr T. P. M. Beelen, was synthesized according to an adaptation by $\mathrm{Zwart}^{7}$ of the method described by Weber and Busch. ${ }^{13}$

2-Mercaptoethanol (Fluka) was distilled prior to use and kept under nitrogen. All other reagents were from analytical purity and used without further purification.

\subsection{Measuring procedures and calculating methods}

The procedure for the catalytic measurements has already been published. ${ }^{2}$ The liquid phase concentration of oxygen was calculated from the composition of the gas mixture as previously published. ${ }^{2}$ During the homogeneous catalytic reactions and the stopped-flow experiments with 2,4-ionene, the $\mathrm{pH}(8 \cdot 3$ or 8.85$)$ was maintained by addition of a trisethylenediamine buffer. The total ionic strength $(0 \cdot 10 \mathrm{M})$ was maintained by adding sodium chloride.

All other catalytic reactions were performed without the use of buffers, in these cases, the $\mathrm{pH}$ was initially adjusted with $\mathrm{NaOH}$; the measurements in dependence of ionic strength were carried out at $\mathrm{pH}=10 \cdot 3$ and the reactions with the PS-qPVP blockcopolymer at $\mathrm{pH}=8.7$. In the latter case no extra salt was added. All reactions were carried out at $25.0 \pm 0.5^{\circ} \mathrm{C}$ at a stirring speed of $2600 \mathrm{rpm}$ in a modified Warburg apparatus. ${ }^{14}$

The stopped-flow measurements were carried out as described by Balt and Meuldijk. ${ }^{15}$ The first order reaction constants as well as the constants describing the two substrate dependence of the reaction rate were obtained by a non-linear least-squares method.

\section{RESULTS AND DISCUSSION}

\subsection{Homogeneous catalytic reactions}

The reaction of thiols with oxygen generally proceeds according to the following stoichiometry: $:^{1,16}$

$$
\begin{array}{lc}
\text { a. } & \multicolumn{2}{c}{\mathrm{RSH}+\mathrm{O}_{2} \rightarrow \mathrm{RSSR}+\mathrm{H}_{2} \mathrm{O}_{2}} \\
\text { b. } & \frac{\mathrm{RSH}+\mathrm{H}_{2} \mathrm{O}_{2} \rightarrow \mathrm{RSSR}+2 \mathrm{H}_{2} \mathrm{O}}{4 \mathrm{RSH}+\mathrm{O}_{2} \rightarrow 2 \mathrm{RSSR}+2 \mathrm{H}_{2} \mathrm{O}} \\
\text { c. } & \rightarrow 2 \text { cheme } 1
\end{array}
$$

In general, reaction $1 \mathrm{~b}$ can be considered as a very rapid consecutive reaction. ${ }^{4}$

The initial rate is calculated from the maximum of the oxygen consumption curve and expressed as the amount of thiol (mol) converted per mol of catalyst per second, taking into account the stoichiometry of Scheme 1. First order kinetics in $\mathrm{CoPc}\left(\mathrm{NaSO}_{3}\right)_{4}$ were found in all cases ${ }^{2,5}$ for this reaction.

At $\mathrm{pH}=8.85$, the initial reaction rates were measured at various oxygen and thiolate anion concentrations. Thiolate anion concentrations were used because we considered this anion to be the reactive species. ${ }^{2}$ The degree of thiol dissociation, calculated as reported previously, ${ }^{2}$ was 0.3 at $\mathrm{pH}=8.85$.

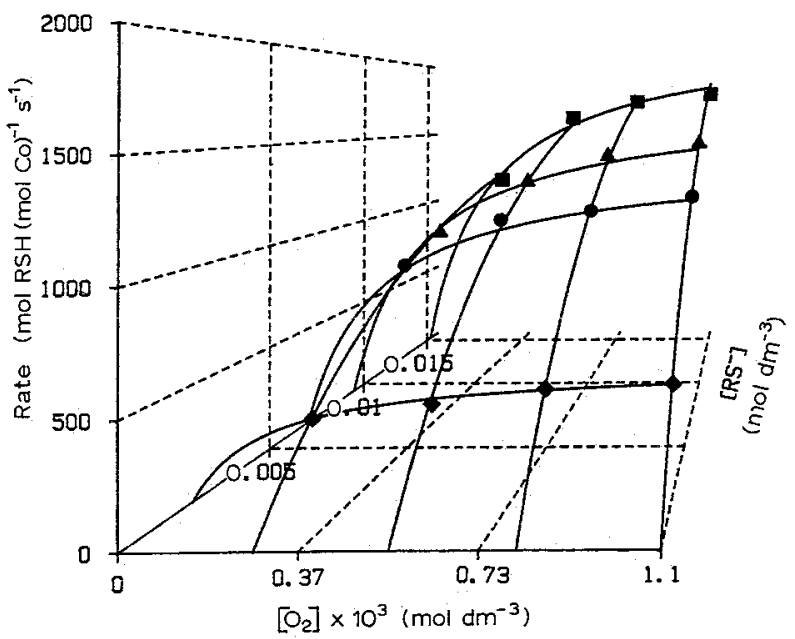

Fig. 4. Initial reaction rate as a function of thiolate anion concentration and dissolved oxygen concentration. Thiolate anion concentrations $1.54 \times 10^{-2} \mathrm{~mol} \mathrm{dm}{ }^{-3},(\mathbf{D}) ; 9.4 \times 10^{-3}$ $\mathrm{mol} \mathrm{dm}{ }^{-3},(\boldsymbol{\Delta}) ; 6.8 \times 10^{-3} \mathrm{~mol} \mathrm{dm}{ }^{-3},(\mathbf{O}) ; 2.1 \times 10^{-3} \mathrm{~mol}$ $\mathrm{dm}^{-3}$, (৬). $T=25 \cdot 0 \pm 0.5^{\circ} \mathrm{C}, I=0.1 \mathrm{M}, \mathrm{pH}=8 \cdot 85 \pm 0.05$. Curves calculated according to eqn (1).

The dependence of reaction rate on both the thiolate anion concentration and the dissolved oxygen concentration showed Michaelis-Menten type of curves (Fig. 4) as also found earlier. ${ }^{2}$ At $\mathrm{pH}=8.85$ saturation of the reaction rate was reached earlier than in the case of $\mathrm{pH}=8 \cdot 3 .^{2}$

The reaction mechanism can schematically be represented by a two substrate Michaelis-Menten scheme. $^{2}$ 


$$
\begin{gathered}
E+S_{1} \underset{k_{-1}}{\stackrel{k_{1}}{\rightleftarrows}} \dot{E} S_{1} \\
E S_{1}+S_{2} \underset{k_{-2}}{\stackrel{k_{2}}{\longrightarrow}} E S_{1} S_{2} \\
E S_{1} S_{2} \underset{k_{3}}{\stackrel{+}{\longrightarrow}} E+P \\
+S_{1}
\end{gathered}
$$

Scheme 2

where $E=\mathrm{CoPc}\left(\mathrm{NaSO}_{3}\right)_{4}, S_{1}=$ thiolate anion and $S_{2}=$ dissolved oxygen. ${ }^{2}$

The reaction rate is then given $b^{2}$

$$
-r=\frac{C_{1}}{1+\frac{C_{2}}{\left[\mathrm{O}_{2}\right]}+\frac{C_{3}}{\left[R S^{-}\right]}+\frac{C_{2} \times C_{4}}{\left[\mathrm{O}_{2}\right]\left[R S^{-}\right]}}
$$

with $C_{1}=4 k_{3}, C_{2}=\left(k_{-2}+k_{3}\right) / k_{2}, C_{3}=k_{3} / k_{1}$ and $C_{4}=k_{-1} / k_{1}$.

This model describes the two-substrate dependence of the reaction rate very well, as illustrated by Fig. 4 , in which the drawn lines are calculated according to eqn 1 . The fitted parameters $\left(C_{1}-C_{4}\right)$ are shown in Table 1 , together with the previously obtained constants at $\mathrm{pH}=8 \cdot 3$. $^{2}$

The parameters $C_{1}-C_{4}$ allow the direct calculation of some of the rate and equilibrium constants of Scheme 2 (see Table 1). The constants $k_{2}$ and $K_{2}$ can only be estimated in limiting cases (see Table 1 ). From Table 1 it can also be seen that all constants are more or less $\mathrm{pH}$ dependent, except for the value of $k_{3}$, the turnover number. An increase of $\mathrm{pH}$ strongly retards $k_{-1}$, indicating an acid catalyzed dissociation of the thiolate anion in which protonation of the coordinated thiolate anion strongly enhances the dissociation rate of this group. A further more elaborate study, on the influence of $\mathrm{pH}$ and of the type of ionene, will be published separately. ${ }^{17}$

Scheme 2 shows that two molecules of thiol are involved in the $\mathrm{CoPc}\left(\mathrm{NaSO}_{3}\right)_{4}$ catalyzed part of the thiol oxidation. However, in the kinetic measurements, no second order behaviour was found for thiol. ${ }^{2,5,7,17}$ This means that one of the thiol additions does not affect the overall rate of reaction. Such a situation might, for example, occur when thiol participates in a fast saturated pre-equilibrium. The question arises whether this concentrationindependent step is the first addition of a thiolate anion to the cobalt complex or the second addition of a thiolate anion to the coordinated thiol radical (Scheme 2). In Scheme 2 it is suggested that the first coordination of a thiolate anion is the step reflecting Michaelis-Menten kinetics in thiol. If this is true, $k_{1}$ and $k_{-1}$ (Table 1) will represent the rate constants of the thiol coordination. Due to the large values of the reaction constants, fast mixing techniques, e.g. stopped-flow spectroscopy, should be used to investigate this first step.

\subsection{Stopped-flow measurements and spectro- scopic measurements}

In principle, it is possible to investigate the coordination of a thiolate anion by the fast mixing of oxygen-free solutions of $\mathrm{CoPc}\left(\mathrm{NaSO}_{3}\right)_{4}$ and thiol, both in the presence of $1 \times 10^{-3} \mathrm{~mol} \mathrm{dm}^{-3} \mathrm{~N}^{+}(2,4-$ ionene). Three consecutive reactions were observed at $450 \mathrm{~nm}$, under both $\mathrm{pH}$ conditions $8 \cdot 3$ and 8.85 . Only the first reaction observed is a likely candidate for the thiol coordination step. The other two reactions appear to be redox reactions. Assuming first order behaviour in $\mathrm{CoPc}\left(\mathrm{NaSO}_{3}\right)_{4}$ a rate constant $\left(k_{o b s d}\right)$ can be calculated. This rate constant for the attainment of equilibrium is dependent on

TABLE 1. Michaelis-Menten constants for the $\mathrm{CoPc}\left(\mathrm{NaSO}_{3}\right)_{4}$ catalyzed thiol oxidation at $\mathrm{pH}=8 \cdot 3^{2}$ and $\mathrm{pH}=\mathbf{8} \cdot 85$ respectively

\begin{tabular}{lcc}
\hline $\mathrm{pH}$ & 8.3 & 8.85 \\
$C_{1}$ & $4300 \pm 400 \mathrm{~s}^{-1}$ & $4250 \pm 250 \mathrm{~s}^{-1}$ \\
$C_{2}$ & $1.4 \times 10^{-4} \pm 0.3 \times 10^{-4} \mathrm{M}$ & $3.1 \times 10^{-4} \pm 0.6 \times 10^{-4} \mathrm{M}$ \\
$C_{3}$ & $6 \times 10^{-3} \pm 0.16 \times 10^{-2} \mathrm{M}$ & $1.4 \times 10^{-2} \pm 1.9 \times 10^{-3} \mathrm{M}$ \\
$C_{4}$ & $2.15 \times 10^{-2} \pm 0.5 \times 10^{-2} \mathrm{M}$ & $6.5 \times 10^{-3} \pm 2 \cdot 1 \times 10^{-3} \mathrm{M}$ \\
$K_{1}\left(=k_{1} / k_{-1}\right)$ & $46 \mathrm{~mol}^{-1}$ & $152 \mathrm{~mol}^{-1}$ \\
$k_{1}$ & $1.8 \times 10^{5} \mathrm{~mol}^{-1} \mathrm{~s}^{-1}$ & $7.6 \times 10^{4} \mathrm{~mol}^{-1} \mathrm{~s}^{-1}$ \\
$k_{-1}$ & $3.9 \times 10^{3} \mathrm{~s}^{-1}$ & $0.5 \times 10^{3} \mathrm{~s}^{-1}$ \\
$K_{2}\left(=k_{2} / k_{-2}\right)^{a}$ & $7.1 \times 10^{3} \mathrm{~mol}^{-1}$ & $3.2 \times 10^{3} \mathrm{~mol}^{-1}$ \\
$k_{2}^{b}$ & $7.7 \times 10^{6} \mathrm{~mol}^{-1} \mathrm{~s}^{-1}$ & $3.4 \times 10^{6} \mathrm{~mol}^{-1} \mathrm{~s}^{-1}$ \\
$k_{3}$ & $1075 \mathrm{~s}^{-1}$ & $1063 \mathrm{~s}^{-1}$ \\
Average fitting error & $5 \%$ & $2 \%$ \\
\hline
\end{tabular}

\footnotetext{
${ }^{a} K_{2}$ calculated under the condition $k_{-2} \gg k_{3}$.

${ }^{b} k_{2}$ calculated under the condition $k_{-2} \ll k_{3}$.
} 
thiol concentration according to: $k_{o b s d}=k_{1}$ [thiol] $+k_{-1}$. The observed rate constant increased from $3.3 \mathrm{~s}^{-1}$ at $0.014 \mathrm{M}$ thiol to $10.9 \mathrm{~s}^{-1}$ at $0.112 \mathrm{M}$ thiol at a $\mathrm{pH}$ of $8 \cdot 3$. From these data an equilibrium constant of $35 \mathrm{~mol}^{-1}$ was estimated for this thiol coordination equilibrium. However, this first observable reaction is probably not the coordination of a thiolate anion to $\mathrm{CoPc}\left(\mathrm{NaSO}_{3}\right)_{4}$ because the initial extinction observed at $t=0$ is already much higher than expected for $\mathrm{CoPc}\left(\mathrm{NaSO}_{3}\right)_{4}{ }^{1,3}$ Therefore, a preceding reaction is bound to occur on a much faster time scale than detectable by the stopped-flow technique $\left(k>10^{3} \mathrm{~s}^{-1}\right)$.

This observation fits in with the large reaction rate constants calculated from the catalytic reaction rates (Table 1). We therefore assume that the second coordination site is occupied by a thiolate anion so that the coordination of a thiolate anion to a thiol cobalt complex is observed as the first trace in the stopped-flow measurement. These experiments do not provide conclusive evidence on the question of which thiol addition is reflected in the Michaelis-Menten kinetics. On the other hand, the present stopped-flow data are not in conflict with Scheme 2.

In order to obtain an estimate of the equilibrium constant of the thiol coordination to $\mathrm{CoPc}\left(\mathrm{NaSO}_{3}\right)_{4}$, several other ligands were investigated spectrophotometrically in their interaction with $\mathrm{CoPc}\left(\mathrm{NaSO}_{3}\right)_{4}$. The following compounds were mixed with a solution of $\mathrm{CoPc}\left(\mathrm{NaSO}_{3}\right)_{4}$ $\left(5 \times 10^{-6} \mathrm{~mol} \mathrm{dm}^{-3}\right)$; NaSCN, 2-mercaptoethanol (at $\mathrm{pH}=1$ ), 2-hydroxyethyl disulphide (the reaction product), thiourea and pyridine. Only in the case of pyridine did clear spectral changes occur when the ligand was added at concentrations above $0.1 \mathrm{M}$. From these data we infer that, in general, coordinative equilibria with $\mathrm{CoPc}\left(\mathrm{NaSO}_{3}\right)_{4}$ will have low equilibrium constants. Therefore, the coordination of a thiolate anion to $\mathrm{CoPc}\left(\mathrm{NaSO}_{3}\right)_{4}$ is likely to show up in the Michaelis-Menten kinetics. The fact that the undissociated 2-mercaptoethanol (see spectrophotometric measurements at $\mathrm{pH}=1$ ) does not coordinate is in agreement with the assumption that the thiolate anion is the reactive species in the thiol oxidation.

\subsection{Reaction mechanism of the $\mathrm{CoPc}\left(\mathrm{NaSO}_{3}\right)_{4}$ catalyzed thiol oxidation in the presence of poly (quaternary ammonium salts)}

On the basis of these and previous observations, ${ }^{1,3}$ we now postulate a reaction mechanism for the $\mathrm{CoPc}\left(\mathrm{NaSO}_{3}\right)_{4}$ catalyzed thiol oxidation in the presence of poly(quaternary ammonium salts) as shown in Fig. 5.

We know that in the presence of ionenes

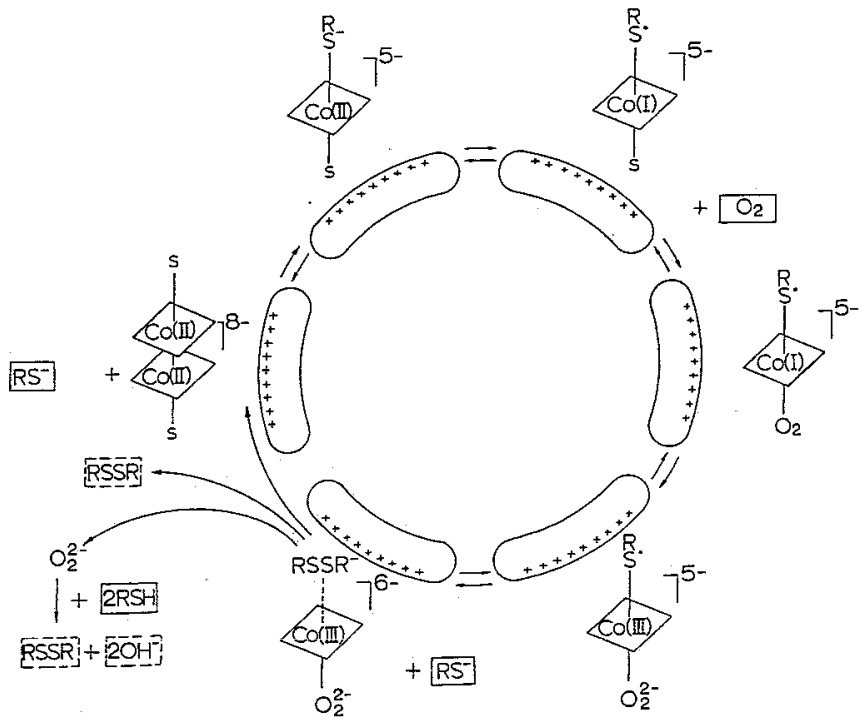

Fig. 5. Proposed reaction mechanism for the $\mathrm{CoPc}\left(\mathrm{NaSO}_{3}\right)_{4}$ catalyzed thiol oxidation in the presence of poly(quaternary ammonium salts). $\mathrm{RSH}$ and $\mathrm{RS}^{-}$are the thiol and the thiolate anion, respectively, $\mathrm{s}$ is the solvent (water), $\mathrm{O}_{2}^{2-}$ can be present in the form of either $\mathrm{OOH}^{-}$or $\mathrm{H}_{2} \mathrm{O}_{2}$.

$\mathrm{CoPc}\left(\mathrm{NaSO}_{3}\right)_{4}$ is present in the form of straight dimers. ${ }^{1,3}$ It has not yet been established if these dimers persist in the catalytic cycle. From the fact that first order kinetics in $\mathrm{CoPc}\left(\mathrm{NaSO}_{3}\right)_{4}$ were found in all cases, it can be concluded that there is no equilibrium between monomer and dimer in the presence of polymers during the catalytic cycle.

The first step in Fig. 5 involves the binding of a thiolate anion, followed by the reduction of $\mathrm{Co}$ (II) to $\mathrm{Co}(\mathrm{I})$ and the simultaneous oxidation of the thiolate anion to a thiol radical. These two steps (Fig. 5) make up Step 1 in Scheme 2 and in our opinion this first equilibrium gives rise to the observed Michaelis-Menten kinetics in thiol.

The next step is the addition of molecular oxygen, followed by a two-electron oxidation of $\mathrm{Co}(\mathrm{I})$ to Co(III) by oxygen and the formation of peroxide. Depending on $\mathrm{pH}, \mathrm{HOO}^{-}$or $\mathrm{H}_{2} \mathrm{O}_{2}$ is produced and one or two $\mathrm{H}^{+}$ions are involved in the peroxide formation respectively. Thus a $\mathrm{pH}$ dependence is introduced in the $k_{2} / k_{-2}$ equilibrium in the catalytic cycle (Fig. 5) (Step 2 in Scheme 2).

The last step is a fast combination of a second thiolate anion with the thiol radical, followed by the reduction of $\mathrm{Co}$ (III) to $\mathrm{Co}$ (II) and the simultaneous formation of disulphide. The rate of this step is independent of the thiol concentration and is part of Step 3 in Scheme 2. The Co(II) complex formed is unstable and falls apart in disulphide, peroxide and the initial catalyst, i.e., the dimer of $\mathrm{CoPc}\left(\mathrm{NaSO}_{3}\right)_{4}$.

The liberated peroxide can convert another 2 moles of thiol into disulphide. In most cases, this reaction of peroxide with thiol can be regarded as a 
fast consecutive reaction, resulting in a stoichiometry of the conversion of 4 thiol molecules per molecule of oxygen. In a separate publication the peroxide reaction and the possible accumulation of peroxide in the catalyzed thiol oxidation reaction will be reported. ${ }^{18}$

In comparison with the polymer free thiol oxidation, the main difference in the kinetic behaviour lies in the fact that we now obtain a positive order in oxygen concentration. In the polymer-free system, at high oxygen concentrations, a negative order is observed. ${ }^{7}$ This discrepancy is caused by the absence of oxygen-bridged dimers in the presence of ionenes. ${ }^{1,3}$ These oxygen-bridged dimers were known to retard the reaction rate to a large extent. ${ }^{7} \mathrm{Zwart}^{7}$ proposed two parallel reaction mechanisms, a reductive and an oxidative catalytic cycle. Both the high reaction rate and the positive reaction order in oxygen observed in the present polymeric systems can be explained by a shift from the oxidative reaction cycle to the reductive reaction cycle for the catalytic thiol oxidation in the presence of ionenes. Our presently proposed reaction mechanism resembles the reductive path of the mechanism proposed by $\mathrm{Zwart}^{7}$ to a large extent.

In effect, the addition of poly(quaternary ammonium salts) drastically increases the rate of the $\mathrm{CoPc}\left(\mathrm{NaSO}_{3}\right)_{4}$ catalyzed thiol-oxidation by changing the reaction mechanism as compared with the reaction mechanism of polymer-free systems. The combination of structural and kinetic information suggests a reaction mechanism no longer affected by the adverse effects of the oxygen bridged dimers. The role of the direct dimers, for instance whether or how they persist during the catalytic cycle, is not yet clear. This interesting question is the subject of further investigations in our laboratory.

\section{4 lonic strength dependence}

In the polymer-free catalytic system an increase of ionic strength was found to increase reaction rate. ${ }^{5}$ This increase in reaction rate is due to the partial compensation of charge repulsion of the negatively charged $\mathrm{CoPc}\left(\mathrm{SO}_{3}\right)_{4}^{4-}$ and the thiolate anion. Part of the rate enhancement caused by the addition of the ionenes to the catalytic system also has to be attributed to the compensation of charge repulsion by the positively charged ammonium groups on the polymer. When salt is added to the polymeric systems, more anions will compete with the thiolate anions for cationic sites on the polymer and therefore the reaction rate is expected to decrease. This effect is shown in Fig. 6 at a $\mathrm{pH}=10 \cdot 3$. At this $\mathrm{pH}$, thiol is mainly present as thiolate anions. For the previously performed experiments at $\mathrm{pH}=7.5$ the ionic strength dependence appeared to be

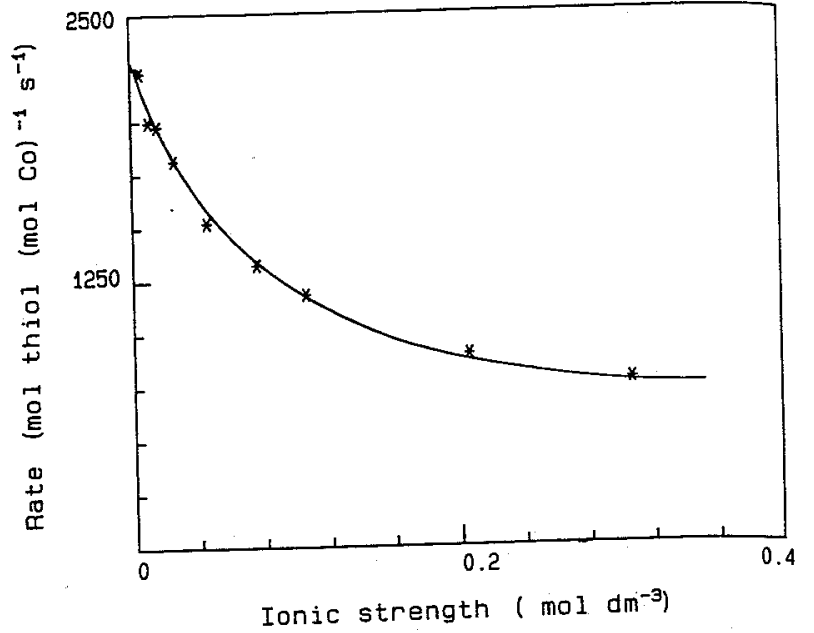

Fig. 6. Initial reaction rate as a function of ionic strength (added sodium chloride), 2-mercaptoethanol $=0.14 \mathrm{~mol} \mathrm{dm}^{-3}$, $\mathrm{pH}=10 \cdot 3, \quad T=25 \cdot 0 \pm 0.5^{\circ} \mathrm{C}, \quad \mathrm{CoPc}\left(\mathrm{NaSO}_{3}\right)_{4}=2 \times 10^{-7}$
$\mathrm{~mol} \mathrm{dm}$

stronger. ${ }^{5}$ At lower $\mathrm{pH}$ less thiol dissociation will occur and therefore adding anions will lead to an increased competitive ion effect and a larger rate retardation.

The measurements aimed at obtaining kinetic information to elucidate the reaction mechanism were all carried out at an ionic strength of $0.1 \mathrm{M}$. As compared with zero ionic strength, this leads to a decrease in rate by a factor of 2 (Fig. 6).

When comparing $k_{3}$ from Table 1 with values found previously at approximately zero ionic strength, ${ }^{5,6}$ it turns out that $k_{3}$ is both independent of ionic strength and $\mathrm{pH}$. This observation can be expected because the $k_{3}$ step is independent of thiol concentration and is therefore, in principle, not affected by changes in the thiol concentration induced by changes in ionic strength or $\mathrm{pH}$. In the experiments aimed at investigating the effects of immobilization, no extra electrolyte was added in order to obtain intrinsic reaction rates as high as possible in these cases.

\subsection{Immobilization of ionenes and influence on the catalytic activity}

The immobilization of these highly active ionene $/ \mathrm{CoPc}\left(\mathrm{NaSO}_{3}\right)_{4}$ catalytic systems on an insoluble support, such as polystyrene resins, inevitably leads to a decrease in reaction rate because of mass transport limitations. An insoluble support with a very high specific outer surface and without pores is believed to overcome these limitations. Latex particles, obtained through emulsion (co)polymerization, with a diameter between 50 and $500 \mathrm{~nm}$ possess the above mentioned properties and therefore offer interesting perspectives as catalyst 
carrier materials. ${ }^{19}$ In our strategy, poly(quaternary ammonium salts) should be anchored to the surface of a latex particle by only a single link to give the polymeric coil the opportunity to expand and solubilize as much as possible.

One possible strategy to obtain the desired morphology of these latex particles is the use of a polymeric soap. This polymeric soap should then consist of a water soluble block containing the ammonium groups and a hydrophobic part that can be incorporated in the hydrophobic part of the latex particle during the emulsion polymerization process. The polymeric soap that stabilizes the latex particle should not desorb. This can be achieved either by physical attachment (entanglements) or by chemical attachment (chain-transfer or co-polymerization reactions) of the hydrophobic part to the polymeric core of the latex particle. The block co-polymer of polystyrene and quaternized polyvinylpyridine (Fig. 3) combines these requirements and can be used as a polymeric soap type of surfactant in a conventional emulsion (co)polymerization. It is essential that the resulting latex particles do not contain any extractable soap molecules because even very low concentrations of soluble poly(quaternary ammonium salts) are capable of enhancing the reaction rate considerably. ${ }^{6}$

The latex was synthesized according to a conventional emulsion copolymerization of styrene and divinyl benzene, with PS-qPVP as surfactant. The resulting latex contained $2.4 \times 10^{-3} \mathrm{~mol} \mathrm{~N}^{+} \mathrm{dm}^{-3}$ as inferred from elemental analysis; the solid content was $0.26 \mathrm{wt} \%$. The particle diameter was approximately $400 \mathrm{~nm}$ as determined from scanning electron microscopy. The latex was purified by mixing with a five-fold excess of cation exchanger, ${ }^{16}$ combined with serum replacement. The latex was isolated by filtrating the ion exchanger over a paper filter.

The presence of free block co-polymer molecules in the serum was checked in two different ways:

(1) by measuring the activity of the isolated serum which was obtained from a serum replacement cell and

(2), by checking the occurrence of $\mathrm{CoPc}\left(\mathrm{NaSO}_{3}\right)_{4}$ dimers when dissolving this catalyst in the serum.

At low concentrations of $\mathrm{CoPc}\left(\mathrm{NaSO}_{3}\right)_{4}$ a dimeric species will only occur when poly(quaternary ammonium salts) are present in the serum. The latter method can detect quantities of polymer in the range of $1 \times 10^{-7} \mathrm{~mol} \mathrm{dm}-3.1$ Both methods indicated the absence of free polymeric soap molecules in the serum $\left(<2 \times 10^{-7} \mathrm{~mol} \mathrm{dm}^{-3}\right)$.

Both the purified latex and the dissolved PS-qPVP block co-polymer were used in combination with
$\mathrm{CoPc}\left(\mathrm{NaSO}_{3}\right)_{4}$ as a catalyst for the oxidation of 2mercaptoethanol. In Fig. 7 the activity is shown as a function of the amount of added catalyst, both for the homogeneous and heterogeneous catalytic system.

Two interesting features immediately arise from these dependencies: the heterogeneous latex catalyst is, most surprisingly, more active than the homogeneous PS-qPVP catalyst and secondly, the activities show a linear dependence on the amount of catalyst. The latter observation indicates that no mass transfer limitations occur in our reactive latex catalyzed reaction. Mass transfer limitations can either be expected to occur at the phase boundary from gas to liquid or in the stagnant film around the latex particle where the reaction is taking place.

It therefore becomes feasible to immobilize our very active catalyst system on latex particles without loss of activity. The latex particles, as prepared, carry a high positive charge and therefore, in the vicinity of the particles, the concentration of both the tetravalent negatively charged catalyst molecule and the negatively charged substrate is greatly enhanced. ${ }^{2}$ This effect may even be more pronounced for the latex particles as compared with the homogeneous PS-qPVP catalyst because of the higher charge density in the diffuse double layers surrounding the latex particles. The linear relationship between activity and amount of catalyst shown in Fig. 7 not only means that mass transfer limitations can be excluded but also means that the degree of enhancement of the anion concentration does not change with catalyst concentration (note that the ratio $\mathrm{N}^{+} / \mathrm{Co}$ does not change in Fig. 7). As a

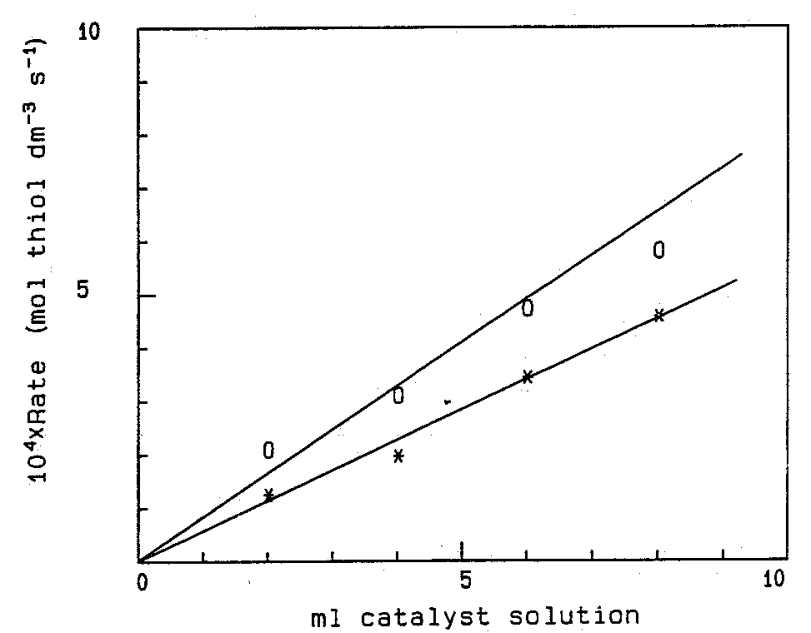

Fig. 7. Initial reaction rate as a function of the amount of catalyst solution $(\mathrm{ml}), 2$-mercaptoethanol $=0.14 \mathrm{~mol} \mathrm{dm}^{-3}$, $\mathrm{pH}=8 \cdot 7, T=25 \pm 0.5^{\circ} \mathrm{C}$. The catalyst solutions both contain $1 \times 10^{-5} \mathrm{~mol} \mathrm{dm}^{-3} \mathrm{CoPc}\left(\mathrm{NaSO}_{3}\right)_{4}$; homogeneous PS-qPVP catalyst, $\left[\mathrm{N}^{+}\right]$in the catalyst solution is $2 \cdot 2 \times 10^{-3} \mathrm{~mol} \mathrm{dm}^{-3}$, $(*)$; heterogeneous PS-qPVP latex bound catalyst, $\left[\mathrm{N}^{+}\right]$in the catalyst solution is $1.2 \times 10^{-3} \mathrm{~mol} \mathrm{dm}{ }^{-3},(\bigcirc)$. 
consequence every latex particle can be considered as an independent micro reactor.

The fact that the latex system is even more active than the dissolved PS-qPVP block co-polymer may either be a specific effect of the latex or a loss of activity of the homogeneous catalyst caused by the presence of the hydrophobic part in the block copolymer which serves no function in this case. We think the latter possibility is the most likely cause of the observed difference. Similar effects were found by Fitch et $a l^{20}$ for reactive latex particles in the sucrose inversion reaction.

When 2,4-ionene is immobilized on XAD-2 resin particles with an average particle size of $80 \mu \mathrm{m}$, a relatively large loss of reaction rate is observed, ${ }^{21}$ in contrast to the immobilization of PS-qPVP units on latex particles where the activity in the presence of $\mathrm{CoPc}\left(\mathrm{NaSO}_{3}\right)_{4}$ is maintained.

The stability of quaternized polyvinylpyridine in successive catalytic runs is not so high ${ }^{12}$ whereas, on prolonged use, the stability of ionenes in homogeneous catalytic reactions is much better. ${ }^{5}$ Therefore, a logical step is the immobilization of ionenes on latex particles, which presumably could lead to both a very active and a very stable catalyst. The synthesis of these types of reactive latex particles is not straightforward, however, several strategies to attach ionene chains via a single link to latex particles have been investigated in our laboratory. The first preliminary results also indicate that the ionene based catalysts can be immobilized onto latex particles without loss of activity.

\section{CONCLUSIONS}

By combining structural information of $\mathrm{CoPc}\left(\mathrm{NaSO}_{3}\right)_{4}$ with kinetic data obtained under various conditions, a reaction mechanism could be postulated that explains the observed Michaelis-Menten kinetics and the polymeric effects that were found.

The reaction rate constants calculated from the kinetic data according to the postulated reaction mechanism are very large. The magnitude of these rate constants is in agreement with the findings obtained in the stopped-flow experiments. The stopped-flow experiments showed that, under certain conditions, a second molecule of thiol can coordinate to $\mathrm{CoPc}\left(\mathrm{NaSO}_{3}\right)_{4}$ at the beginning of the catalytic cycle, which might lead to complications in the reaction mechanism in certain cases. The dependence of the reaction rate on ionic strength also supports our view that the thiolate anion is the reactive species in the catalytic cycle. It further shows that at high ionic strength large rate retardations occur.

The immobilization of this highly active catalytic system, especially at low ionic strength, is a very challenging goal, since mass transfer limitations are expected to occur to a considerable degree. Therefore an active latex was synthesized, indeed resulting in an immobilized catalyst, maintaining the high activity of the homogeneous systems. These active latices offer very promising perspectives, especially in those catalytic reactions, like the present model reaction concerning the $\mathrm{CoPc}\left(\mathrm{NaSO}_{3}\right)_{4}$ catalyzed thiol oxidation, where intrinsic reaction rates are very high.

\section{ACKNOWLEDGEMENTS}

The authors are indebted to Ms Ir. A. Tullemans, Ir. J. Hof and Ir. R. Tennebroek for performing parts of the measurements and also to Professor S. Balt (Free University of Amsterdam) for providing the opportunity to use the stopped-flow apparatus.

\section{REFERENCES}

1 van Welzen, J., van Herk, A. M. \& German, A. L., Makromol. Chem., Macromol. Chem. Phys., 188 (1987) 1923.

2 van Herk, A. M., Tullemans, A. H. J., van Welzen, J. \& German, A. L., J. Mol. Catal., 44 (1988) 269.

3 van Welzen, J., van Herk, A. M. \& German, A. L., Makromol. Chem. (in press).

4 Schutten, J. H. \& Zwart, J., J. Mol. Catal., 5 (1979) 109.

5 Brouwer, W. M., Macromolecular effects on the oxidation of thiols, PhD thesis, Eindhoven, 1984; Brouwer, W. M., Piet, P. \& German, A. L., Polymer Bulletin, 8 (1982) 245.

6 van Streun, K. H., Piet, P. \& German, A. L., Eur. Polym. J., 23 (1987) 941.

7 Zwart, J., Catalytic oxidation of throlson polymer attached cobalt phthalocyanine complexes, PhD thesis, Eindhoven, 1978.

8 Rembaum, A., Baumgartner, W. \& Eisenberg, E., J. Polym. Sci. Part C: Polym. Lett., 6 (1969) 159.

9 Ishizu, K., Gamoo, S., Fukutomi, T. \& Kakurai; T., Makromol. Chem., 183 (1982) 3099.

10 Kurihara, M., Kamachi, M. \& Stille, J. K., J. Polym. Sci., Part A: Polym. Chem., 11 (1973) 587.

11 Vanderhoff, J. W., van den Hul, H. J., Tansk, R. J. M. \& Overbeek, J. Th. G. In Clean Surfaces: Their Application and Characterization for Interfacial Studies, ed. G. Goldfinger, Marcel Dekker, New York, 1970, p. 15.

12 Tennebroek, R., Internal Report No. 30 , available on request.

13 Weber, J. H. \& Busch, P. H., Inorg. Chem., 4 (1965) 469.

14 Brouwer, W. M., Piet, P. \& German, A. L., J. Mol. Catal., 31 (1985) 169.

15 Balt, S. \& Meuldijk, J., Z. Naturforsch., Teil B, 34 (1979) 843.

16 Yatsimirskii, A. K., Kozlyak, E. I., Erohkin, A. S., Vigderganz, V. E. \& Berezin, I. V., React. Kinet. Catal. Lett., 34 (1987) 439.

17 Kramer, H., Internal Report, No. 31a, available on request.

18 Kramer, H., Internal Report, No. 31b, available on request.

19 Hassanein, M. \& Ford, W. T., Macromolecules, 21 (1988) 526.

20 Fitch, R. M., Mallya, P. K., McCarvill, W. T. \& Miller, R. S. In Abstracts of communications of the 27th International Symposium on Macromolecules, Strasbourg, 6-9 July 1981.

21 van Streun, K. H., Meuldijk, J. \& German, A. L., Angew. Makromol. Chem. (in press). 